\title{
Correction to: Genome-wide characterization of the cellulose synthase gene superfamily in Pyrus bretschneideri and reveal its potential role in stone cell formation
}

\author{
Guohui Li ${ }^{1} \cdot$ Xin Liu $^{1} \cdot$ Yuxuan Liang ${ }^{2} \cdot$ Yang Zhang $^{1} \cdot$ Xi Cheng $^{1} \cdot$ Yongping Cai ${ }^{1}$ \\ Published online: 11 September 2020 \\ (C) Springer-Verlag GmbH Germany, part of Springer Nature 2020
}

Correction to: Functional \& Integrative Genomics (2020) https://doi.org/10.1007/s10142-020-00747-8

The above article was published online with the same Figures 7 and 8 . The correct figure 8 is presented here. The Original Article has been corrected.

The online version of the original article can be found at https://doi.org/ $10.1007 / \mathrm{s} 10142-020-00747-8$

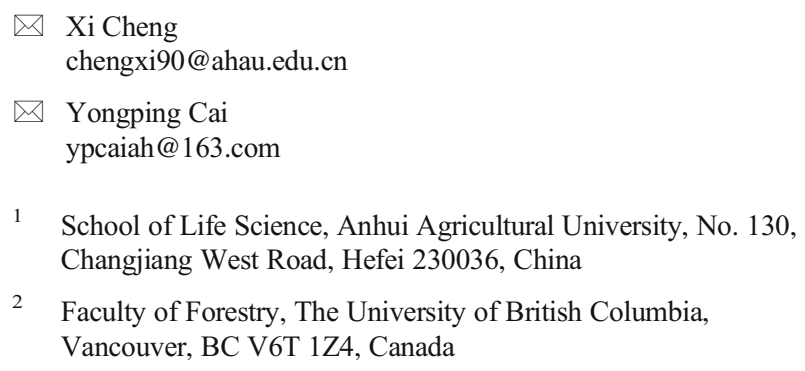

2 Faculty of Forestry, The University of British Columbia, Vancouver, BC V6T 1Z4, Canada 


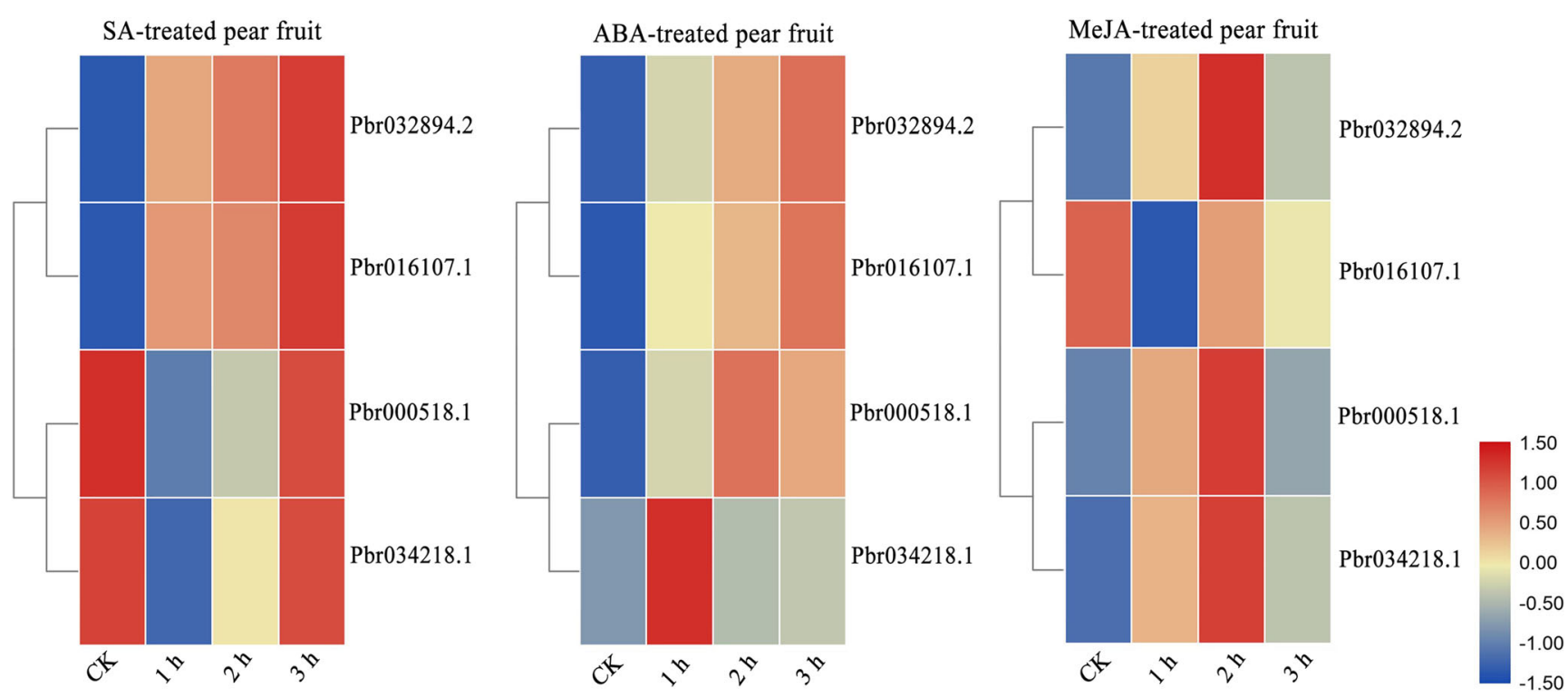

Fig. 8 Expression patterns of $\mathrm{PbCes} / \mathrm{Csl}$ genes in response to different hormone treatments. The heatmap was generated by TBtools software using the $\mathrm{PbCes} / \mathrm{Csl}$ genes expression data with hormonal treatments.
Log2-based-fold changes were used to create a heatmap. As shown in the bar at the lower right corner, the gene transcription level is expressed in different colors on the map. Data represent the mean of 3 replicates 